\title{
Building Information Modelling (BIM): the impact of project attributes towards clients' demand in BIM-based project
}

\author{
N. A. H. Hadzaman, R. Takim \& A. H. Nawawi \\ Faculty of Architecture, Planning \& Surveying, \\ Universiti Teknologi MARA (UiTM), Malaysia
}

\begin{abstract}
Building Information Modeling (BIM) is a systematic process used to model information involving the use of computer-generated (n-dimensional) software to simulate the planning, design, construction, and operation of a building. Currently, BIM technology is an important approach used by most project clients (public and private) to boost project effectiveness in terms of time, cost and quality of construction projects to meet client demand. However, previous studies showed that BIM-based project implementation in Malaysia faces greater challenges due to project attributes that causes low demand of project clients to adopt BIM. Hence, the purpose of the paper is to investigate the impact of project attributes towards client demand by adopting BIM across project life cycle. A crosssectional survey was conducted in Malaysia among the three project stakeholders: the public sector, private sector, and contractors using BIM for their projects. Seven (7) significant project attributes (i.e., feasibility, definition, duration, project location, objectives, size and type) and three (3) triangle of client demand (i.e., time; cost; quality) were subjected to Parametric Pearson Correlation. The results showed that there exist a significant relationship between the project attributes and client demand. The results suggest that project clients (public and private) should take a consideration of project attributes in fulfilling the client demand at the early stage of project commencement to maximize the BIM benefits to other stages of construction.

Keywords: attribute, Building Information Modeling (BIM), client demand, Malaysia.
\end{abstract}




\section{Introduction}

Building Information Modeling (BIM) in its formative development in the Architectural, Engineering and Construction (AEC) industry, is a digital representation of physical and functional characteristics of a facility that link the database of project information (Ahmad Latiffi et al. [1]). In line with Ariyaci et al. [2], BIM is defined as the use of ICT technologies to streamline the building project lifecycle processes to provide a safer and more productive environment for its occupants, to assert a list possible environmental impact from its existence, and to be more operationally efficient for its owner throughout the building lifecycle. $\mathrm{BIM}$, as a comprehensive concept of process and tools integrates all projects required data and information, reshaping the way construction project teams work together with the ultimate aim is to deliver a successful project outcomes (i.e., time, cost and quality) (Rohena [3]).

According to Karathodoros and Brynjolfsson [4], many construction players cannot yet recognise the potential benefits of BIM can offer. As such, they are reluctant to implement BIM even the benefits is clearly defined. In contrast, they criticize that implementing BIM will incur additional cost without clear and secure outcome (Khosrowshahi and Ariyaci [5], Karathodoros and Brynjolfsson [4]). Due to the insecure situations and the needs for the nation to become competitive with other developed countries, the success of BIM depends on the project attributes and the current need of the organization (client) involved. By implementing a function of BIM in a simple and low cost project might not have the desired outcome and wide benefits (Karathodoros and Brynjolfsson [4]). A clear project attributes is required to help the client determine whether function of BIM is effectively and successfully utilized to reap the full benefits of BIM. Client should define a project's attributes that are appropriate for utilization of BIM in order to meet the clients' demand in BIM-based project. Hence, the objective of this paper is to investigate the impact of project attributes towards client demand by adopting BIM across project life cycle.

\section{Project attributes in BIM-based project}

The project attributes have seven major attributes: project feasibility, project definition and formulation, project duration, project location, project objectives, size of the project and type of the project. These are crucial to successful BIM project outcomes. According to Kometa and Olomolaiye [6] and Tan [7], the types of the project can be classified into educational, institutional, residential, industrial, commercial, and recreational. The design and construction of the projects depends on the size and project location. According to them, the size of the project considering on the project cost, complexity of the design and construction, gross floor area, building height and technology required. Building projects also deals with the project location from small area to urban development, including remote and confined areas. A project begins with the idea and formulation of a concept, followed by a philosophy and the idea of the certainty in scope of work. A development plan is produced by a feasibility study to see the 
viability and marketability of idea by considering the risk allocation. Project feasibility is needed so that an appropriate action can be taken as preparation before the project commencement. However, in implementing this, there must be certain specialization of personnel appointment towards BIM application. This also enclosed with BIM documentation such as BIM Guidelines, BIM Execution Plan or BIM template to run the BIM process into the project. In order to achieve a successful BIM-based project, it is vital to set the stakeholders' objective, value for money in BIM, and suitable selection method of procurement. These goals could be based on project performance and include items such as reducing the schedule duration, achieving higher field productivity, increasing quality, reducing cost of change orders, or obtaining important operational data for the facility (PSU [8], Jadhav [9]). The problem becomes more complex when dealing with multi-disciplined design environments (Ibrahim [10]) that influenced the briefing stage. In such an environment, it is preferable to bring up the issue of data sharing in terms of formats and platforms at early stage. The best solution is integrating the whole team to the same platform when possible; otherwise it is very crucial to bring up the process of file formats conversion and compatibility.

\section{Time, Cost, and Quality (TCQ) of client demand in BIM-based project}

In the development of a BIM-based project, some project stakeholders failed to appreciate the potential of BIM. As such, to a certain extent it is inevitable for project client to enforce project teams to incorporate BIM in construction projects (Henttinen [11]). Initially, clients' demands are across project phases from strategy formulation until completion. This means to say that client demands in the project to be constructed are within budget and frequent cost information, value adding activities, stipulated time frame, and high standard quality products (PSU [8]). According to Porwal and Hewage [12], clients can drive the significant improvement in the cost, value and carbon performance through the use of BIM as an open and shareable asset information model. One of the most important steps in the planning process is to clearly define the potential value of BIM among project team members through defining the overall demand for BIM implementation. These demands could be based on project performance and include items such as reducing the schedule duration, achieving higher field productivity, increasing quality, reducing cost of change orders, or obtaining important operational data for the facility (PSU [8], Jadhav [9]). It is classified into three iron triangle of client demand (i.e., time; cost; quality), which acts as critical objectives of project success, are not independent, but intricately related in project accomplishment.

Time: major criterion of project success by the clients, contractors, and consultants alike. There is a universal criticism of failure in the construction industry due to the time in delivering the projects. Objective of time in BIM refers to achieving needs of time as stipulated on the benefits of BIM process. The benefits of BIM in time are: to improve design reviews, more faster and effective process, impact of clash detection and better collaboration (Rajendran et al. [13]). 
The clients' objectives can be achieved through an organised interdependence of time, cost, and quality.

Cost: clients mostly are concerned with the overall profitability and accountability of the projects generally. However, through an organised of cost management needs, i.e. resource planning, cost budgeting, cost control and cost estimating will cause to reduce expenses of cost in the projects. Thus, in case of $\mathrm{BIM}$, project saving are considerably high at the early stage of project involvement (design phase). This is due to the coordination issues that could reduce of trade conflicts among project stakeholders. BIM in cost involved reduces the errors in take-off estimating and visualization of construction and fabrication works (Rajendran et al. [13]) that mostly involving the highest cost in the process.

Quality: an ambiguous term to understand differently by different people. It is sometimes defined as activities designed to improve organisation service known as pre-defined standards (Rezaian [14]). Improving quality is to enhance the customer (end-user) satisfaction, function as intended, comfort, and increase productivity. It is also believed that refers to the proper quality management mostly in design and construction phases. It recognised three category of quality: functionality, comfort, and impact (Ahmad [15]). Quality on functionality refers to the arrangement, quantity and inter-relationship of spaces and how the building is designed to fulfil client need. In addition, quality on comfort refers to how well the building is constructed, its structure, engineering system, safety quality, the coordination of the building, and their performance. Meanwhile, quality on impact refers to the ability of the building to delight, uplifts local community and environment, intrigues and design contribution of architecture. Table 1 shows the matrix of the variables of project attributes upon client demand.

Table 1: Project attributes upon client demand.

\begin{tabular}{lccc}
\hline \multicolumn{1}{c}{ Project attributes } & \multicolumn{3}{c}{ Client demand } \\
\cline { 2 - 4 } & Time & Cost & Quality \\
\hline Project feasibility & $\sqrt{ }$ & $\sqrt{ }$ & $\sqrt{ }$ \\
\hline Project definition and formulation & $\sqrt{ }$ & $\sqrt{ }$ \\
\hline Project duration & $\sqrt{ }$ & $\sqrt{ }$ & $\sqrt{ }$ \\
\hline Project objective & $\sqrt{ }$ & $\sqrt{ }$ & \\
\hline Project location & & $\sqrt{ }$ & $\sqrt{ }$ \\
\hline Size of the project & $\sqrt{ }$ & $\sqrt{ }$ \\
\hline Type of project & & \\
\hline
\end{tabular}

\section{Methodology}

The research utilised a structured questionnaire survey method of three principal target groups within the construction industry, focusing on the states of Selangor and Kuala Lumpur in Malaysia. The data of collection exercises were held in Malaysia over a period of one month (26th March to 28th April, 2015). A ten-page structured questionnaire was distributed to the three target groups, representing a mixture of professionals including those dealing with design, construction, project management, quantity surveying, construction, facilities management, and clients of construction projects. The three targeted group were: public sector, private 
sector, and contractors. Samples were randomly selected from the listing provided by the respective professional institutions and Construction Industry Development Board (CIDB) through National BIM Committee. To measure these attributes, afive-points Likert type scaled items were deployed for which the participants were asked to indicate their level of agreement and disagreement.

As shown in Table 2, a total number of 85 questionnaires were sent out to the target groups (public sector, private sector, and contractors) within the construction industry over a period of one month. Out of this, 30 questionnaires were completed and returned representing a response rate of 35.29 percent which is acceptable in construction management research (Dulami et al. [16]). Thirteen respondents $(44.83 \%)$ were from the public sector, followed by 12 respondents $(32.43 \%)$ from the private sector and 5 respondents $(26.32 \%)$ from the contractors. The poor response from contractors could be due to the limited time frame and lack of expertise and knowledge in BIM. The range of respondents experience in term of years in the BIM is between 2 and 6 years. This is expected due to BIM was just introduced in Malaysia construction industry since 2007, representing an executive level of experience in the sample. Despite the volume of questionnaire (10 pages) is essential to capture the issues of attributes influencing demand in BIM implementation, it might have the responsible for the seemingly low response rate since the data collection are still ongoing for further response for the purpose of $\mathrm{PhD}$ main data collection. Nevertheless, off late this questionnaire was completed by the various respondents in Malaysia, thus, give some of confidence that the responses are reliable.

Table 2: Respondents' profile.

\begin{tabular}{cccc}
\hline $\begin{array}{c}\text { Respondents } \\
\text { (type of organisations) }\end{array}$ & $\begin{array}{c}\text { Questionnaire } \\
\text { distributed }\end{array}$ & $\begin{array}{c}\text { Responses } \\
\text { returned }\end{array}$ & $\begin{array}{c}\text { Percentage } \\
\text { of responses (\%) }\end{array}$ \\
\hline Public sector & 29 & 13 & 44.83 \\
\hline Private sector & 37 & 12 & 32.43 \\
\hline Contractors & 19 & 5 & 26.32 \\
\hline TOTAL & $\mathbf{8 5}$ & $\mathbf{3 0}$ & $\mathbf{3 5 . 2 9}$ \\
\hline
\end{tabular}

\section{Data analysis, findings and discussion}

\subsection{Reliability of data}

Cronbach's Alpha is the most common method of examining the reliability in internal consistency. The calculation of the Cronbach's Alpha is based on the number of items and the average inter-item correlation. It ranges from ' 0 ' for a complete unreliable test to ' 1 ' for completely reliable test (Hinton et al. [17], Pallant [18], Coakes and Ong [19]). Nunally [20] suggests in the range of 0.50 0.60, while Hinton et al. [17], Takim [21], and Takim et al. [22] suggest the scale range of $0.50-0.75$. Table 3 shows the result for the reliability based on the Cronbach's Alpha value. The result presented show that the Cronbach's Alpha is in the range of 0.559-0.957 indicating that the data collected are interrelated and reliable. 
Table 3: Reliability of data.

\begin{tabular}{lcc}
\hline \multicolumn{1}{c}{ Category } & Cronbach's Alpha & No. of Item \\
\hline Project feasibility & 0.890 & 6 \\
\hline Project duration and formulation & 0.894 & 4 \\
\hline Project duration & 0.892 & 5 \\
\hline Project objective & 0.903 & 3 \\
\hline Project location & 0.829 & 8 \\
\hline Size of the project & 0.800 & 6 \\
\hline Type of project & 0.873 & 6 \\
\hline Time & 0.559 & 7 \\
\hline Cost & 0.951 & 12 \\
\hline Quality (functionality, comfort, and impact) & 0.957 & 35 \\
\hline
\end{tabular}

\subsection{Parametric Pearson correlation}

A correlation analysis is preformed to describe the strength and direction of the two variables co-relates. According to Pallant [18], correlation provides an indication that there is a relationship between two variables, however it did not indicate that one variable cause another. The statistical measures value from - 1 to +1 where -1 indicates a perfect negative correlation, to +1 indicates a perfect positive correlation. A correlation of 0 indicates no relationship between the two variables. Pearson's coefficient of correlation indicates the two variables must be quantitative and normally distributed. A strong correlation indicates there is only a small amount of error whilst, a weak correlation indicates a lot of error and the points are more scattered. As cited in Pallant [18], he suggested a small $r=0.10$ to 0.29 , medium $r=0.30$ to 0.49 , and large $r=0.50$ to 1.0 . Since the data obtained is normally distributed, the parametric Pearson correlation is employed to determine the relationship of project attributes and client demand.

Table 4 shows the result of correlation between project attributes impact client demand in BIM-based project. It can be seen that there is a strong relationship between 'project feasibility' and 'cost' with negative correlation of $r$ value = 0.673, (p-value $=0.000<0.05$ ). This is in line with Rajendran et al. [13], that project savings are considerably high when using BIM at the early phase of the projects. Moreover, a medium positive coefficient of correlation value, $r=0.442$ between 'project feasibility' and 'time'. This is corroborates with O'Brien [23] that selection of wrong technology in the early phase of BIM project commencement at the same time will affects the performance.

The next project attributes is project definition and formulation. It can be seen that there is a strong relationship between 'project definition and formulation' and 'quality' with positive correlation of $r$ value $=0.614$. This implies that the scope of work such as accuracy in detailed BIM design will increase the quality of construction projects (Ahmad Latiffi et al. [24]).

Besides, a strong positive coefficient of correlation between 'project duration' and 'quality' with $\mathrm{r}$ value of 0.578 occurred. According to Rajendran et al. [13], BIM assist in system coordination through clash analysis tools to discover and resolve conflict which affected the quality of the building. Therefore, project duration could be shorter and quality of the building is achieved. 
Table 4: Results of correlation.

\begin{tabular}{|c|c|c|c|c|c|c|c|c|c|c|}
\hline & & 2 & 3 & 4 & 5 & 6 & 7 & 8 & 9 & 10 \\
\hline 1 & $\begin{array}{l}\text { Project } \\
\text { feasibility }\end{array}$ & $\begin{array}{c}0.686^{* *} \\
0.000\end{array}$ & $\begin{array}{c}0.751^{* *} \\
0.000\end{array}$ & $\begin{array}{c}0.697^{* *} \\
0.000\end{array}$ & $\begin{array}{l}0.457^{*} \\
0.011\end{array}$ & $\begin{array}{c}0.379^{*} \\
0.039 \\
\end{array}$ & $\begin{array}{c}0.497^{* *} \\
0.005\end{array}$ & $\begin{array}{c}-0.673^{* * *} \\
0.000\end{array}$ & $\begin{array}{l}0.301 \\
0.106 \\
\end{array}$ & $\begin{array}{c}0.442^{*} \\
0.014\end{array}$ \\
\hline 2 & $\begin{array}{l}\text { Project } \\
\text { definition and } \\
\text { formulation }\end{array}$ & & $\begin{array}{c}0.918^{* *} \\
0.000\end{array}$ & $\begin{array}{c}0.847^{* *} \\
0.000\end{array}$ & $\begin{array}{c}0.734^{* *} \\
0.000\end{array}$ & $\begin{array}{l}0.415^{*} \\
0.023\end{array}$ & $\begin{array}{l}0.403^{*} \\
0.027\end{array}$ & $\begin{array}{l}-0.030 \\
0.875\end{array}$ & $\begin{array}{c}0.614^{* *} \\
0.000\end{array}$ & $\begin{array}{l}0.224 \\
0.234\end{array}$ \\
\hline 3 & $\begin{array}{l}\text { Project } \\
\text { duration }\end{array}$ & & & $\begin{array}{c}0.692^{* *} \\
0.000\end{array}$ & $\begin{array}{c}0.604^{* *} \\
0.000\end{array}$ & $\begin{array}{c}0.512^{* *} \\
0.004\end{array}$ & $\begin{array}{l}0.433^{*} \\
0.017\end{array}$ & $\begin{array}{l}-0.213 \\
0.258 \\
\end{array}$ & $\begin{array}{c}0.578^{* *} \\
0.001\end{array}$ & $\begin{array}{l}0.259 \\
0.168\end{array}$ \\
\hline 4 & $\begin{array}{l}\begin{array}{l}\text { Project } \\
\text { objective }\end{array} \\
\end{array}$ & & & & $\begin{array}{c}0.639^{* *} \\
0.000\end{array}$ & $\begin{array}{l}0.114 \\
0.549 \\
\end{array}$ & $\begin{array}{l}0.153 \\
0.418 \\
\end{array}$ & $\begin{array}{l}-0.195 \\
0.302 \\
\end{array}$ & $\begin{array}{l}0.246 \\
0.190 \\
\end{array}$ & $\begin{array}{l}0.209 \\
0.267\end{array}$ \\
\hline 5 & $\begin{array}{l}\text { Project } \\
\text { location }\end{array}$ & & & & & $\begin{array}{c}0.481^{* *} \\
0.007\end{array}$ & $\begin{array}{l}0.144 \\
0.447\end{array}$ & $\begin{array}{l}0.029 \\
0.880\end{array}$ & $\begin{array}{c}0.703^{* *} \\
0.000\end{array}$ & $\begin{array}{c}-0.144 \\
0.448\end{array}$ \\
\hline 6 & $\begin{array}{l}\text { Size of the } \\
\text { project }\end{array}$ & & & & & & $\begin{array}{c}0.697^{* *} \\
0.000\end{array}$ & $\begin{array}{l}-0.101 \\
0.594\end{array}$ & $\begin{array}{l}0.539^{* *} \\
0.002\end{array}$ & $\begin{array}{l}0.194 \\
0.304\end{array}$ \\
\hline 7 & $\begin{array}{l}\text { Type of } \\
\text { project }\end{array}$ & & & & & & & $\begin{array}{c}-0.234 \\
0.213\end{array}$ & $\begin{array}{l}0.349 \\
0.059\end{array}$ & $\begin{array}{l}0.305 \\
0.102\end{array}$ \\
\hline 8 & Cost & & & & & & & & $\begin{array}{l}0.337 \\
0.069\end{array}$ & $\begin{array}{c}-0.070 \\
0.713\end{array}$ \\
\hline & Quality & & & & & & & & & $\begin{array}{l}0.175 \\
0.354 \\
\end{array}$ \\
\hline
\end{tabular}

10 Time

**Correlation is significant at the 0.01 level (2-tailed).

*Correlation is significant at the 0.05 level (2-tailed).

A strong positive coefficient of correlation revealed a value, $r=0.703$ between the 'project location' and 'quality'. This may be due to the complexity of location with large scope of work will always associated with a high value of quality. According to Kozak [25], BIM could be apply to any area of project since BIM significantly help in quality design and the delivery for the entire project.

Based on the results, the 'size of the project' has a strong positive coefficient of correlation towards 'quality' with $\mathrm{r}$ value of 0.539 . This implies that the complexity in design requirement due to the size of the project could be eliminate by design review in early stage through integration all parties involved in BIM-based projects and significantly remain quality (value for money) (Rajendran et al. [13], Bowen and Cattel [26]).

\subsection{Comparative discussion}

Table 5 shows a comparison of result between literature search and questionnaire survey. The literature search consist of seven attributes namely, feasibility, definition, duration, project location, objectives, size and type and triangle of client demand (i.e., time, cost, quality).

The first key attributes discussed the project feasibility as the basis of client demand consisting the time, cost, and quality as according to Rajendran et al. [13], by triggering at the early stage of the project. Despite BIM could reduce the project costs through systematic collaboration, it also provide future building visualization in term of performance (quality) and time saving for the client. Nevertheless, the coefficient correlation result failed to show that quality is correlated to project 
feasibility. This is due to the fact that most of respondents were from the private sectors (developers) that are mostly concern on the time and cost instead of quality deliverables.

Table 5: Comparison of results.

\begin{tabular}{|c|c|c|c|c|c|c|}
\hline \multicolumn{4}{|c|}{ Literature review } & \multirow{2}{*}{\multicolumn{3}{|c|}{$\begin{array}{c}\text { Questionnaire analysis } \\
\text { Parametric Pearson correlation }\end{array}$}} \\
\hline \multirow[t]{2}{*}{ Project attributes } & \multicolumn{3}{|c|}{ Client demand } & & & \\
\hline & Time & Cost & Quality & Time & Cost & Quality \\
\hline Project feasibility & $\sqrt{ }$ & $\sqrt{ }$ & $\sqrt{ }$ & $\sqrt{ }$ & $\sqrt{ }$ & \\
\hline $\begin{array}{l}\text { Project definition } \\
\text { and formulation }\end{array}$ & $\sqrt{ }$ & & $\sqrt{ }$ & & & $\sqrt{ }$ \\
\hline Project duration & $\sqrt{ }$ & & & & & $\sqrt{ }$ \\
\hline Project objective & $\sqrt{ }$ & $\sqrt{ }$ & $\sqrt{ }$ & & & \\
\hline Project location & & $\sqrt{ }$ & & & & $\sqrt{ }$ \\
\hline Size of the project & $\sqrt{ }$ & $\sqrt{ }$ & $\sqrt{ }$ & & & $\sqrt{ }$ \\
\hline Type of project & & $\sqrt{ }$ & & & & \\
\hline
\end{tabular}

Next, the project definition and formulation that indicates basically on the concept of BIM, platform and scope of work. From the literature search, it showed that Client demand on project time and quality has positive impacts on project definition and formulation. This contradicts to the results of the questionnaire analysis that failed to regard time as important during the project definition and formulation. The probable reason could be due to the fact that BIM in Malaysia has just started and most of the respondents are still unsure of the benefits of BIM that could affect the time and cost problems as mentioned by Rajendran et al. [13].

In project duration, however, once again the results obtained contradict to findings from previous research. Time is correlated in project duration based on literature, however in this research; quality is correlated to project duration based on questionnaire analysis. For that reason, lack of early integration on design reviews has contributed to errors in design and construction. Hence, they perceived BIM could assist in detection of errors and omissions for building quality purposes (Rajendran et al. [13]).

Another essential point is the correlation between project attributes of project objective with time, cost, and quality. Surprisingly, there is no correlation found from the questionnaire analysis. The probable reason for this predicament is that most of the project objective is determined by the top management, hence the support from top management is an important element for adopting BIM technology (Zakaria et al. [27]) in determining projects' objective.

Once again, in term of project location, the literature search revealed that cost is much correlated by the location of the project such as rural, swampy or remote areas. Surprisingly, the results of the questionnaire analysis failed to be in line with the literature search. The justification for the dilemma is that, in Malaysia, project quality used to be emphasised by most construction players in particular when dealing with BIM-based project (Rajendran et al. [13]) at remote areas. This means to say that cost is not the main problem with regards to the high risk projects.

Besides, the coefficient correlation revealed that the impact of size of the projects is only correlated to project quality and not to time and cost. The 
contention could be due to most of BIM-based projects that are of high complexity in design requirement and to date, there is no standard of BIM implementation guidelines in Malaysia at the national level (Zakaria et al. [27]). As such size and quality is very much correlated compared to time and cost. Since the data collected based on perception, some of the respondents could misinterpret the purpose of the study.

Finally, there is no coefficient correlation that appear from the questionnaire analysis in term of time, cost, and quality to type of the project. The reason is that the implementation of BIM-based project for educational, industrial, commercial, and institutional in Malaysia is still low and stagnant (Zakaria et al. [27]).

\section{Conclusion}

This paper examines the current views on identifying the correlation of project attributes towards client demand. The project attributes have revealed seven (7) attributes. These are: feasibility, definition, duration, project location, objectives, size and type, while the three triangle of client demand are: time, cost, and quality. In the end, the findings revealed six (6) coefficient correlations of the impacts. These are: project feasibility is correlated to time and cost; project definition and formulation, project duration, project location, size of the project are all correlated to quality. Undoubtedly, these findings indicate that quality is the most essential factor by most Malaysian construction players in BIM-based project. Although the sample is small (30 respondents) for the time being, it findings cannot be discredit. Further research is to explore the relationship between the client attributes and client demand and the result will be reported in due course.

The research presented in this paper is part of an on-going $\mathrm{PhD}$ research study at the Faculty of Architecture, Planning and Surveying, UiTM Malaysia to develop a framework of client governing in Building Information Modeling (BIM) implementation. The result of the study could provide an insight into Malaysian construction projects environment and could offer a valuable guideline, in particular to industry players that are going to implement BIM based-projects.

\section{References}

[1] A. Ahmad Latiffi, J. Brahim, S. Mohd, and M. S. Fathi, "The Malaysian Government's Initiatives in using Building Information Modeling (BIM) in Construction Pojects," Sustain. Solut. Struct. Eng. Constr., no. Cream, pp. 767-772, 2014.

[2] Y. Ariyaci, C. Egbu, and P. Coates, "Building Inofrmation Modelling (BIM) Implementation and Remote Construction Projects: Issues, Challenges, and Critiques," J. Inf. Technol. Constr., vol. 17, no. May, pp. 75-92, 2012.

[3] R. Rohena, "Building Information Management (BIM) Implementation in Naval Construction," 2011.

[4] G. Karathodoros and O. R. Brynjolfsson, "Governing the implementation of BIM," Chalmers University of Technology, 2013. 
[5] F. Khosrowshahi and Y. Ariyaci, "Roadmap for implementation of BIM in the UK construction industry," Eng. Constr. Archit. Manag., vol. 19, no. 6, pp. 610-635, 2012.

[6] S. T. Kometa and P. O. Olomolaiye, "Attributes of UK construction clients influencing project consultants' performance," Constr. Manag. Econ., vol. 12, 1994.

[7] A. A. L. Tan, Project management in Malaysia. Kuala Lumpur: Prentice Hall Press, 1996.

[8] Penn State University (PSU) "BIM Project Execution Planning Guide," 2010.

[9] M. Jadhav, "Better buildings through digital practice : Change in roles and processes," Delft University of Technology, 2011.

[10] M. Ibrahim, "To BIM or not to BIM, This is NOT the Question: How to Implement BIM Solutions in Large Design Fim Environments," 2006. [Online]. Available at:

https://www.academia.edu/373207/To_BIM_or_not_to_BIM_this_is_NO T_the_question_How_to_Implement_BIM_Solutions_in_Large_Design_F irm_Environments

[11] T. Henttinen, "BIM in Finland," Finland, 2010.

[12] A. Porwal and K. N. Hewage, "Building Information Modeling (BIM) partnering framework for public construction projects," Autom. Constr., vol. 31, pp. 204-214, May 2013.

[13] P. Rajendran, T. Seow, and K. Goh, "Bulding Information Modeling (BIM) in design stage to assist in time, cost and quality in construction innovation," Int. J. Conceptions Manag. Soc. Sci., vol. 2, no. 3, pp. 52-55, 2014.

[14] A. Rezaian, "Time-cost-quality-risk of construction and development projects or investment," Middle-East J. Sci. Res., vol. 10, no. 2, pp. 218223, 2011.

[15] N. Ahmad, "The influence of client attributes on project success: A focus on the briefing stage," Universiti Teknologi MARA (UiTM), 2008.

[16] M. F. Dulami, F. Y. Y. Ling, and A. Bacrajharya, "Organisational motivation and inter-organisational interaction in construction innovation in Singapore," Constr. Manag. Econ., vol. 21, no. 3, 2003.

[17] P. R. Hinton, C. Brownlow, I. McMurray, and B. Cozens, SPSS Explained. New York: Routledge, 2004.

[18] J. Pallant, SPSS Survival Manual: A step by step guide to data analysis using IBM SPSS, 5th Editio. USA: Mc Graw Hill, 2013.

[19] S. J. Coakes and C. Ong, SPSS Version18.0 for Windows: Analysis without ANguish, Version 18. John Wiley \& Sons Australia, 2011.

[20] I. Nunally, Psychometric Theory. New York: Mc Graw Hill, 1978.

[21] R. Takim, "A framework for successful construction project performance," Glasgow Caledonian University, 2005.

[22] R. Takim, S. M. Shaari, and R. M. Nordin, “Transparency Initiative (TI) for Enhancing Quality of Life: Behavioural Components that Lead to Corruption in Construction," Procedia-Soc. Behav. Sci., vol. 101, pp. 110119, Nov. 2013. 
[23] W. J. O’Brien, “Implementation Issues In Project Web Sites: A Practitioners Viewpoint," J. Manag. Eng., vol. 16, no. June, pp. 34-39, 2000.

[24] A. Ahmad Latiffi, S. Mohd, N. Kasim, and M. S. Fathi, "Building Information Modeling (BIM) Application in Malaysian Construction Industry," vol. 2, pp. 1-6, 2013.

[25] A. Kozak, "Improving design quality and total project delivery with Building Information Modeling," p. 8700, 2012.

[26] P. Bowen and K. Cattel, "Perceptions of time, cost and quality management on building projects," Australas. J., vol. 2, no. 2, pp. 48-56, 2012.

[27] Z. Zakaria, N. M. Ali, A. T. Haron, A. Marshall-ponting, and Z. Abd, "Exploring the Adoption of Building Information Modelling (BIM) in the Malaysian Construction Industry: A Qualitative Approach," Int. J. Res. Eng. Technol., vol. 02, no. 08, pp. 384-395, 2013. 